\title{
The shunt from hell: management based on the point of obstruction
}

\author{
Harold L Rekate \\ From Hydrocephalus 2015 \\ Banff, Canada. 18-21 September 2015
}

\section{Introduction}

After two years of study and conversation a group of 20 hydrocephalus investigators developed a consensus on a new classification of hydrocephalus based on point of obstruction. This new classification has proved useful in the diagnosis and treatment of patients with hydrocephalus of all types and is especially helpful in assessing the various treatment options for the individual patient.

\section{Methods}

This is a retrospective review of a patient with a complex form of hydrocephalus related to a Dandy Walker Malformation who had had over 60 shunt revisions in the two years prior to first being seen at our insitution. She was evaluated as to potential points of obstruction and the best treatment for each point. The plan was to make certain that all compartments containing CSF were to be made to communicate with each other and that a maximum of one valve would be used if further treatment is needed.

\section{Results}

Using injections of Iohexal tracer for $\mathrm{CT}$ it was shown that there were very small lateral and third ventricles and obstruction to flow from through the aqueduct and from the cortical subarachnoid space into the encysted fourth ventricle. Treatment progressed in stages with fenestration of the cyst and replacing the shunt with a reservoir and "Butterfly needle." The lateral and third ventricle dilated and it was shown that now there was a fourth ventricle containing a floppy collapsed cyst within it. Following endoscopic third ventriculostomy she is now without a shunt and is back to school for the first time in 2 years. Follow up is 9 months.

\section{Discussion}

The vast majority of cases of hydrocephalus are due to distinct sites of obstruction to flow of CSF. Normal CSF dynamics demand that all CSF compartements communicate freely and that the intracranial pressures are normal. At this point if the ventricles are able to increase in size the patient is likely ( $>80 \%$ ) to be able to be managed without a shunt with or without an endoscopic third ventriculostomy.

Published: 18 September 2015

\section{References}

1. Rekate HL: A consensus on the classifecation of hydrocephalus: its uility in the assessment of abnormalities of cererbrospinal fluid. Childs Nerv Syst 2011, 1535-41.

2. Rekate $\mathrm{HL}$, et al: The importance of the cortical subarachnoid space in understanding hydrocpehlus. J NeurosurgPediatr 2008, 1-11.

3. Rekate HL Shunt-related headaches: the slit ventricle syndromes. Childs Nerv Syst 2008, 24(423-30).

doi:10.1186/2045-8118-12-S1-P45

Cite this article as: Rekate: The shunt from hell: management based on the point of obstruction. Fluids and Barriers of the CNS 2015 12(Suppl 1): P45.

Submit your next manuscript to BioMed Central and take full advantage of:

- Convenient online submission

- Thorough peer review

- No space constraints or color figure charges

- Immediate publication on acceptance

- Inclusion in PubMed, CAS, Scopus and Google Scholar

- Research which is freely available for redistribution 